\title{
Aviation fuel tracer simulation: Model intercomparison and implications
}

\author{
M.Y. Danilin ${ }^{1}$, D.W. Fahey ${ }^{2}$, U. Schumann ${ }^{3}$, M.J. Prather ${ }^{4}$, J.E. Penner ${ }^{5}$, \\ M.K.W. Ko ${ }^{1}$, D.K. Weisenstein ${ }^{1}$, C.H. Jackman ${ }^{6}$, G. Pitari ${ }^{7}$, I. Köhler ${ }^{3}$, \\ R. Sausen ${ }^{3}$, C.J. Weaver ${ }^{6}$, A.R. Douglass ${ }^{6}$, P.S. Connell ${ }^{8}$, D.E. Kinnison ${ }^{8}$, \\ F.J. Dentener ${ }^{9}$, E.L. Fleming ${ }^{6,10}$, T.K. Berntsen ${ }^{11}$, I.S.A. Isaksen ${ }^{12}$, \\ J.M. Haywood ${ }^{13}$, and B. Kärcher ${ }^{3}$
}

\begin{abstract}
An upper limit for aircraft-produced perturbations to aerosols and gaseous exhaust products in the upper troposphere and lower stratosphere (UT/LS) is derived using the 1992 aviation fuel tracer simulation performed by eleven global atmospheric models. Key findings are that subsonic aircraft emissions: 1) have not be responsible for the observed water vapor trends at $40^{\circ} \mathrm{N} ; 2$ ) could be a significant source of soot mass near $12 \mathrm{~km}$, but not at $20 \mathrm{~km}, 3$ ) might cause a noticeable increase in the background sulfate aerosol surface area and number densities (but not mass density) near the northern mid-latitude tropopause, and 4) could provide a global, annual mean top of the atmosphere radiative forcing up to $+0.006 \mathrm{~W} / \mathrm{m}^{2}$ and $-0.013 \mathrm{~W} / \mathrm{m}^{2}$ due to emitted soot and sulfur, respectively.
\end{abstract}

\section{Introduction}

Atmospheric effects of aviation are a focus of ongoing NASA and European Programs [e.g., Stolarski et al, 1995; Friedl, 1997; Schumann et al., 1997; Brasseur et al., 1998] and the forthcoming IPCC Special Report on Aviation and the Global Atmosphere. Until recently, most research concentrated on the ozone layer's response to emissions of $\mathrm{NO}_{x}$ and $\mathrm{H}_{2} \mathrm{O}$ by the current subsonic and projected supersonic aircraft fleets. However, in situ measurements of the Concorde exhaust [ $\mathrm{Fa}$ hey et al., 1995] showed a surprisingly large amount of very small sulfate particles, presumably due to rapid oxidation of exhaust $\mathrm{SO}_{2}$. Subsequent model calculations [Weisenstein et al., 1996] showed these small particles, despite their small total mass, could significantly enhance the stratospheric surface area density (SAD) and alter the ozone balance in the lower stratosphere. Like-

\footnotetext{
${ }^{1}$ Atmospheric and Environmental Research, Inc., Cambridge, Massachusetts

2NOAA Aeronomy Lab, Boulder, Colorado

3DLR Institute of Atmospheric Physics, Oberpfaffenhofen, Germany

${ }^{4}$ University of California, Irvine, California

${ }^{5}$ University of Michigan, Ann Arbor, Michigan

${ }^{6}$ NASA Goddard Space Flight Center, Maryland

${ }^{7}$ University of L'Aquila, L'Aquila, Italy

${ }^{8}$ Lawrence Livermore National Lab, Livermore, California

${ }^{9}$ Utrecht University, Utrecht, The Netherlands

${ }^{10}$ Space Application Corp., Vienna, Virginia

${ }^{11}$ Center for International Climate and Environmental Research, Oslo, Norway

${ }^{12}$ University of Oslo, Oslo, Norway

${ }^{13}$ Meteorological Office, UK
}

Copyright 1998 by the American Geophysical Union.

Paper number GRL-1998900058.

0094-8276/98/GRL-1998900058\$05.00 wise, the recent SUCCESS campaign studied the potential for aircraft to produce persistent contrails and possibly to induce cirrus formation [ $G R L$, nos.8-10, 1998]. Thus aircraft emission of particles (sulfate, soot, metals, etc.), or of particle precursors $\left(\mathrm{SO}_{2}, \mathrm{H}_{2} \mathrm{O}\right)$, have become a significant source of uncertainty in current environmental assessment studies.

Evaluating the environmental impact of the subsonic fleet is a very difficult issue due to the following problems. First, emissions occur near the tropopause, which is a region of large gradients in most chemical species and is the interface between two very different meteorological regimes; stratosphere/troposphere exchange is poorly understood; and measurements near the tropopause are as difficult to interpret as to model. Second, the transition in aerosol chemistry across the tropopause is complex as it changes from liquid sulfuric acid and water to a more complicated liquid-solid mix in the troposphere that includes ammonia, organics, and crustal materials [GRL, no.9, 1998]. Third, aerosol distributions in the UT/LS are inhomogeneous, especially near convective regions or flight corridors, requiring computationally intensive $3-D$ models to simulate their patterns rather than the longitudinally averaged 2-D models traditionally used for stratospheric ozone assessments.

This study uses a suite of global 3-D and 2-D models to predict the atmospheric accumulation and dispersion of exhaust products from the 1992 subsonic fleet. We intercompare the models to derive uncertainty ranges since no measurements exist that uniquely allow us to measure the accumulation of subsonic exhaust products in the UT/LS region. Upper limits for the buildup of aviation-induced aerosols as well as stratospheric $\mathrm{H}_{2} \mathrm{O}$ are derived. We consider whether subsonic emissions could explain recent measurements of stratospheric soot or water vapor. The impacts on heterogeneous chemistry through changes in surface area density are also evaluated, as well as the changes in radiative forcing of climate through aerosol-radiation coupling.

\section{Aviation Fuel Tracer Simulation}

Four 2-D and seven 3-D global model choose to participate in this study (see Table 1). We assume that these eleven models can provide uncertainty bounds for the model calculations. The 3-D models have independently derived meteorologies. Some focus on the troposphere and lower stratosphere (e.g. ECHAM3, UIO, TM3), while others cover the whole stratosphere as well. The 2-D models have independently formulated zonalmean residual transport and diffusion and focus on simulating stratospheric ozone. For this fuel tracer simulation, each model provided identical diagnostics on a standard grid ( $5^{\circ}$ latitude by $2 \mathrm{~km}$ altitude) of the steady-state, zonally and annually averaged distribution of aviation fuel emitted according to a 3-D pattern of flight routes designated in the 1992 NASA scenario 
Table 1. Results from the 1992 aviation fuel tracer simulation

\begin{tabular}{|c|c|c|c|c|c|c|c|c|c|c|}
\hline Model $^{1}$ & $\begin{array}{l}\text { Resolution, } \\
\text { lat } \times \text { alt } \\
\text { or } \\
\text { lat } \times \text { lon } \times \text { alt }\end{array}$ & $\begin{array}{l}\text { Maxi- } \\
\text { mum, } \\
\text { ng/g }\end{array}$ & $\begin{array}{l}\text { Lat. } \\
\text { of } \\
\max . \\
{ }^{o} \mathrm{~N}\end{array}$ & $\begin{array}{l}\text { Global } \\
\text { resid. } \\
\text { time, } \\
\text { days }\end{array}$ & $\begin{array}{c}\text { Tracer in } \\
8-16 \mathrm{~km} \\
30 \mathrm{~N}-90 \mathrm{~N}, \\
\%\end{array}$ & $\begin{array}{l}\% \text { of } \\
\text { tracer } \\
\text { above } \\
12 \mathrm{~km}\end{array}$ & $\begin{array}{c}\text { Max. }^{3} \\
\text { tracer } \\
\text { column } \\
\mu \mathrm{g} / \mathrm{cm}^{2}\end{array}$ & $\begin{array}{l}\text { Global } \\
\text { soot } \\
\text { column } \\
\mathrm{ng} / \mathrm{cm}^{2}\end{array}$ & $\begin{array}{c}\text { Global }^{4} \\
\mathrm{SO}_{4} \\
\text { column } \\
\mathrm{ng} / \mathrm{cm}^{2}\end{array}$ & $\begin{array}{c}\text { Model }^{5} \\
\text { descri- } \\
\text { ption }\end{array}$ \\
\hline $\begin{array}{l}\text { AER } \\
\text { GSFC-2D } \\
\text { LLNL } \\
\text { UNIVAQ-2D } \\
\text { ECHAM3 } \\
\text { GSFC-3D } \\
\text { TM3 } \\
\text { UCI/GISS } \\
\text { UIO } \\
\text { UMICH } \\
\text { UNIVAQ-3D }\end{array}$ & $\begin{array}{l}9.5^{\circ} \times 1.2 \mathrm{~km} \\
10^{\circ} \times 2 \mathrm{~km} \\
5^{\circ} \times 1.5 \mathrm{~km} \\
10^{\circ} \times 2.8 \mathrm{~km} \\
5.6^{\circ} \times 5.6^{\circ} \times 2 \mathrm{~km} \\
2^{\circ} \times 2.5^{\circ} \times 2 \mathrm{~km} \\
3.75^{\circ} \times 5^{\circ} \times 1.5 \mathrm{~km} \\
4^{\circ} \times 5^{\circ} \times 2.5 \mathrm{~km} \\
8^{\circ} \times 10^{\circ} \times 3 \mathrm{~km} \\
4^{\circ} \times 5^{\circ} \times 2.75 \mathrm{~km} \\
10^{\circ} \times 22.5^{\circ} \times 2.8 \mathrm{~km}\end{array}$ & $\begin{array}{l}26.7 \\
122 \\
72.5 \\
36.4 \\
12.6 \\
46.7 \\
20.1 \\
34.4 \\
28.2 \\
30.4 \\
38.4\end{array}$ & $\begin{array}{l}55 \\
55 \\
65 \\
60 \\
50 \\
50 \\
80 \\
55 \\
55 \\
65 \\
50\end{array}$ & $\begin{array}{l}38 \\
62 \\
65 \\
23 \\
22 \\
52 \\
21 \\
27 \\
29 \\
45 \\
25\end{array}$ & $\begin{array}{l}34 \\
61 \\
42 \\
58 \\
34 \\
44 \\
45 \\
49 \\
50 \\
37 \\
50\end{array}$ & $\begin{array}{l}45 \\
16 \\
38 \\
33 \\
31 \\
29 \\
40 \\
14 \\
40 \\
44 \\
41\end{array}$ & $\begin{array}{c}6.6 \\
22.9 \\
14.5 \\
7.7 \\
4.1 \\
11.7 \\
4.9 \\
8.2 \\
7.8 \\
9.6 \\
7.7\end{array}$ & $\begin{array}{l}0.11 \\
0.20 \\
0.20 \\
0.08 \\
0.07 \\
0.16 \\
0.07 \\
0.09 \\
0.09 \\
0.14 \\
0.08\end{array}$ & $\begin{array}{l}3.5 \\
5.9 \\
6.0 \\
2.2 \\
2.0 \\
4.9 \\
2.0 \\
2.6 \\
2.7 \\
4.2 \\
2.3\end{array}$ & $\begin{array}{l}\text { W98 } \\
\text { J96 } \\
\text { K94 } \\
\text { P93 } \\
\text { SK94 } \\
\text { W96 } \\
\text { Wa97 } \\
\text { H98 } \\
\text { BI97 } \\
\text { P91 } \\
\text { Pi93 }\end{array}$ \\
\hline
\end{tabular}

${ }^{1}$ The models are denoted as follows: (2-D) Atmospheric and Enironmental Research, Inc (AER), Goddard Space Flight Center (GSFC-2D), Lawrence Livermore National Laboratory (LLNL), University of L'Aquila (UNIVAQ-2D) and (3-D) DLR application of Hamburg GCM (ECHAM3), GSFC-3D model with cloud mass fluxes, Royal Netherlands Meteorological Institute and Utrecht University (TM3), University of Calfornia at Irvine (UCI/GISS), University of Oslo (UIO), University of Michigan (UMICH), and UNIVAQ-3D.

${ }^{2}$ Vertical resolution shown corresponds to the levels near the tropopause.

${ }^{3}$ Column amounts are calculated from 0 to $60 \mathrm{~km}$ for all models except ECHAM3 and TM3 (up to $32 \mathrm{~km}$ ) and UIO (up to $26 \mathrm{~km}$ ).

${ }^{4}$ These values assume EI(sulfur) $=4 \times 10^{-4} \mathrm{~kg}(\mathrm{~S}) / \mathrm{kg}$ (fuel) with $100 \%$ conversion of sulfur to sulfate particles.

${ }^{5}$ W98: Weisenstein et al.[1998]; J96: Jackman et al. [1996]; K94: Kinnison et al. [1994]; P93: Pitari et al. [1993]; SK94: Sausen and Köhler [1994]; W96: Weaver et al. [1996]; Wa97: Wauben et al. [1997]; H98: Hannegan et al. [1998]; BI97: Berntsen and Isaksen [1997]; P91: Penner et al. [1991]; Pi93: Pitari [1993].

[Baughcum et al., 1996] (Figure 1, bottom right, 139.4 $\mathrm{Mt} / \mathrm{yr}$ ). The fuel is transported in the models as a passive tracer. The only tracer sink was globally uniform removal everywhere below $400 \mathrm{hPa}(\sim 7 \mathrm{~km})$ with an e-folding time of 5 days, simulating tropospheric washout.

The mass distribution of a specific exhaust product, $\mathrm{X}$, that is reasonably simulated by this removal process can be obtained by multiplying the tracer mass mixing ratio by the emission index (EI) of $\mathrm{X}$, in $\mathrm{kg}(\mathrm{X}) / \mathrm{kg}$ (fuel) for the purposes of this study. The following EIs are used below: $\mathrm{EI}\left(\mathrm{H}_{2} \mathrm{O}\right)=1.23, \mathrm{EI}$ (soot) $=4 \times 10^{-5}$, and $\mathrm{EI}(\mathrm{S})=4 \times 10^{-4} \mathrm{~kg} / \mathrm{kg}$. Volume mixing ratios for gases can be derived from scaling the mass mixing ratio by $\mu_{\text {air }} / \mu_{\text {tracer }}$ (here $\mu$ is the molar weight).

\section{Results and Discussion}

Figure 1 and Table 1 summarize the principal results of the fuel tracer simulation. The maximum in tracer mixing ratio occurs for all but the TM3 model between $50^{\circ} \mathrm{N}$ and $65^{\circ} \mathrm{N}$ near $10-12 \mathrm{~km}$, consistent with the source distribution. The maximum tracer mixing ratio ranges from $12.6 \mathrm{ng} / \mathrm{g}$ (ECHAM3) to $122 \mathrm{ng} / \mathrm{g}$ (GSFC$2 \mathrm{D})$, reflecting in part the model resolution and in part the uncertainty in modeling the dispersion of aircraft exhaust (i.e. the GSFC-2D and LLNL models have the smallest $\mathrm{K}_{z z}$ and $\mathrm{K}_{y y}$ values there, while the ECHAM3 model has the strongest vertical transport). To smooth the effects of model resolution we calculate the tracer amount in the $8-16 \mathrm{~km}$ altitude region between $30^{\circ} \mathrm{N}$ and $90^{\circ} \mathrm{N}$ (shown by the thick dashed line in Figure 1). This region contains from 34\% (AER, ECHAM3) to $61 \%$ (GSFC-2D) of the total accumulated tracer. The absolute amount of tracer mass in this volume ranges from $2.9 \mathrm{Tg}$ (ECHAM3) to $14.5 \mathrm{Tg}$ (GSFC-2D). The compact latitudinal containment of the tracer poleward of $30^{\circ} \mathrm{N}$ is an encouraging similarity among all models. The amount of tracer transported upward towards the stratospheric ozone maximum is an important diagnostics in the model results. The amount of fuel tracer above $12 \mathrm{~km}$ ranges from 14-16\% (UCI/GISS and GSFC-2D) to 44-45\% (UMICH and AER) of each model's global tracer amount. The models also show very different tracer mass mixing ratios above the lowermost stratosphere, reflecting uncertainties in modeling upward motions and diffusion out of the mid-latitude tropopause region. For example, at $26 \mathrm{~km}$ and $60^{\circ} \mathrm{N}$ the results in Figure 1 vary from 0.9 (UCI/GISS) to $11.2 \mathrm{ng} / \mathrm{g}$ (UMICH). The global residence time of the fuel tracer, defined as the ratio of the steady-state tracer mass to the tracer source, varies from 21-22 days (TM3 and ECHAM3) to 62-65 days (GSFC-2D and LLNL). $\mathrm{H}_{2}$ O. The results of this simulation are used to estimate upper bounds for the contribution of subsonic aviation to the abundances and trends of $\mathrm{H}_{2} \mathrm{O}$ by scaling the tracer distribution by the $\mathrm{EI}\left(\mathrm{H}_{2} \mathrm{O}\right)$. A caveat is that the simple uniform removal timescale of 5 days below $400 \mathrm{hPa}$ may not represent the removal of excess water vapor by the hydrologic cycle. Among the models, the LLNL model gives the largest tracer accumulation at $40^{\circ} \mathrm{N}$ in the lower stratosphere, with values gradually decreasing from $34 \mathrm{ng} / \mathrm{g}$ (or $55 \mathrm{ppbv}$ ) at 10 $\mathrm{km}$ to $8 \mathrm{ng} / \mathrm{g}$ (or $12 \mathrm{ppbv}$ ) at $24 \mathrm{~km}$. Assuming 5\%/yr growth in fuel consumption and $\mathrm{EI}\left(\mathrm{H}_{2} \mathrm{O}\right)=1.23$, one derives a trend of the aircraft-produced $\mathrm{H}_{2} \mathrm{O}$ ranging from $3.4 \mathrm{ppbv} / \mathrm{yr}$ at $10 \mathrm{~km}$ to $0.8 \mathrm{ppbv} / \mathrm{yr}$ at $24 \mathrm{~km}$. For ambient values of water vapor at $40^{\circ} \mathrm{N}$ of $59 \mathrm{ppmv}$ at $10-12$ $\mathrm{km}$ and $4.2 \mathrm{ppmv}$ at $22-24 \mathrm{~km}$ [Oltmans and Hofmann, 1995], the growth in air traffic could produce a trend of $+0.006 \% / \mathrm{yr}$ at $10 \mathrm{~km}$ and $+0.018 \% / \mathrm{yr}$ at $24 \mathrm{~km}$. 

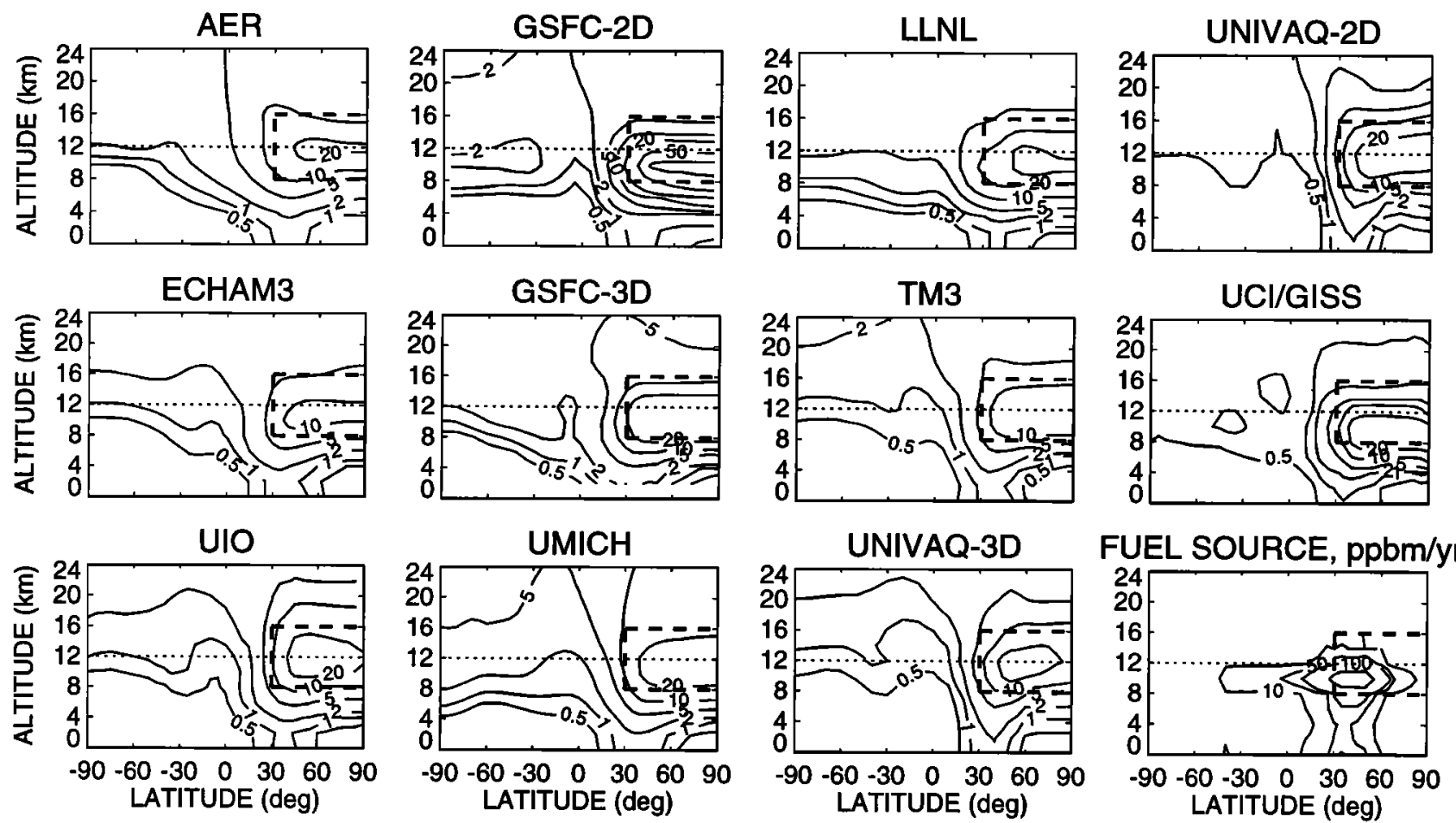

Figure 1. Zonally and annually averaged distribution of the fuel tracer in $\mathrm{ng}$ (tracer)/g(air) from the participating models. The fuel source is shown in the bottom right panel. The thick dashed line shows the region between 8-16 $\mathrm{km}$ and $30^{\circ} \mathrm{N}-90^{\circ} \mathrm{N}$, the thin dashed line depicts the $12 \mathrm{~km}$ altitude.

These trends are a factor of more than 20 less than those reported by Oltmans and Hofmann [1995].

Soot. Calculations for soot with EI(soot) $=4 \times 10-5$ $\mathrm{kg} / \mathrm{kg}$ show the strongest local perturbation of 1.8 $\mathrm{ng} / \mathrm{m}^{3}$ in the GSFC-2D tracer field at $10 \mathrm{~km}$ and $55^{\circ} \mathrm{N}$. Again, caveats must be made regarding the realism of atmospheric scavenging of soot by the parameterized loss below $400 \mathrm{hPa}$. This zonal mean soot mass density is comparable to measured values of up to $2 \mathrm{ng} / \mathrm{m}^{3}$ at 10-12 km [Pueschel et al., 1997] and recent model calculations [Rahmes et al., 1998], indicating that subsonic aircraft can be a noticeable source of soot mass near the northern mid-latitude tropopause. This conclusion is uncertain because we took the maximum predicted concentration and existing measurements are sparse [Pueschel et al., 1997]. Some other 3-D model calculations [Cooke and Wilson, 1996; Liousse et al, 1996] indicate the importance of surface soot sources at $10-12 \mathrm{~km}$ altitude. Aircraft, however, are unable to explain the observed soot at $20 \mathrm{~km}$ [Pueschel et al., 1997]. The fuel tracer simulation does provide a basis to estimate of the perturbation of soot SAD, which is a necessary parameter for heterogeneous chemistry calculations. For example, from the mass balance and assuming the radius of particles $\mathrm{r}=10 \mathrm{~nm}$, density $\rho_{\text {soot }}=$ $2 \mathrm{~g} / \mathrm{cm}^{3}, \mathrm{EI}($ soot $)=4 \times 10^{-5} \mathrm{~kg} / \mathrm{kg}, \rho_{\text {air }}=0.38 \mathrm{~kg} / \mathrm{m}^{3}$, one gets $\mathrm{SAD}_{\text {soot }}=0.28 \mu \mathrm{m}^{2} / \mathrm{cm}^{3}$ for the maximum of the GSFC 2-D output.

Sulfate aerosol. The LLNL model results show the largest amount of sulfate aerosol mass in the stratosphere (16.6 ktons, or only $2.1 \%$ of its background value of 0.8 ktons [G.K. Yue, personal communication]) assuming $\mathrm{EI}(\mathrm{S})=4 \times 10^{-4} \mathrm{~kg} / \mathrm{kg}$ and $100 \%$ conversion of sulfur emissions to sulfate aerosol. As a result, the trend in the stratospheric sulfate aerosol mass due to the subsonic fleet is $0.1 \% / \mathrm{yr}$ if the fuel consumption growth rate is $5 \% / \mathrm{yr}$ and natural sources are constant. This trend is much smaller than the $5 \% / y r$ trend found by Hofmann [1991] and contradicts his inference that the observed trend was due to the sulfur in aircraft fuel. However, our conclusions are consistent with those in Bekki and Pyle [1992].

The contribution of subsonic aircraft to the sulfate aerosol mass at $10 \mathrm{~km}$ and $55^{\circ} \mathrm{N}$ is $110 \mathrm{ng} / \mathrm{m}^{3}$ (GSFC2D) for EI(S) of $4 \times 10^{-4} \mathrm{~kg} / \mathrm{kg}$ and $100 \%$ conversion. This value is several times smaller than the background value [Yue et al., 1994]. Thus, even at the point of maximum accumulation, subsonic aircraft could not perturb the sulfate aerosol mass strongly.

The rapid formation of new nm-sized sulfate particles in aircraft plumes is estimated to vary between $0.4 \%$ [Curtius et al., 1998] and $>12 \%$ [Fahey et al., 1995] of available sulfur emissions. The new sulfate particle formation in the plume determines the perturbations of SAD and hence the heterogeneous chemistry [Weisenstein et al., 1996]. The remaining $\mathrm{SO}_{2}$ gas will oxidize more slowly and condense onto existing sulfate particles, thus contributing to the visible scattering and, hence, climatic impacts. Aircraft perturbations to the sulfate aerosol SAD at altitude $\mathrm{z}$ and latitude $\phi$ are estimated as:

$$
\mathrm{SAD}_{\mathrm{sul}}(\mathrm{z}, \phi)=\frac{3 \operatorname{tr}(\mathrm{z}, \phi) \rho_{\mathrm{air}} \xi \mathrm{EI}(\mathrm{S}) \mu_{\mathrm{H} 2 \mathrm{SO} 4}}{\mathrm{r} \rho_{\mathrm{sul}} \mathrm{wt}_{\mathrm{H} 2 \mathrm{SO} 4} \mu_{\mathrm{S}}}
$$

Here, $\operatorname{tr}(z, \phi)$ is the tracer distribution, $\xi$ is the conversion fraction of sulfur to sulfate, and $\mathrm{wt}_{\mathrm{H} 2 \mathrm{SO}}$ is the weight fraction of $\mathrm{H}_{2} \mathrm{SO}_{4}$ in a particle. Since the uncertainties of the aircraft sulfur emission conversion to new sulfate particles are large, we assume $\xi=5 \%$ for demonstration purposes only. For example, assuming $\mathrm{r}=10 \mathrm{~nm}, \rho_{\text {air }}=3.8 \times 10^{-4} \mathrm{~g} / \mathrm{cm}^{3}, \rho_{\text {sul }}=1.5 \mathrm{~g} / \mathrm{cm}^{3}$, $\mathrm{EI}(\mathrm{S})=0.0004$, and $\mathrm{wt}_{\mathrm{H} 2 \mathrm{SO} 4}=0.5$ (or $50 \%$ ), equation (1) 
gives $1.13 \mu \mathrm{m}^{2} / \mathrm{cm}^{3}$ for the GSFC-2D maximum of 122 $\mathrm{ng} / \mathrm{g}$. This value is comparable to background sulfate SAD and consistent with the results of Kjellström et al [1998]; however, it becomes much smaller than background levels at 16-20 km where heterogeneous chemistry plays an important role in mid-latitude ozone loss.

Direct Radiative Forcing of Climate. The atmospheric accumulation of the fuel tracer is non-uniform with maximum zonal annual mean concentrations of $4.1-23 \mu \mathrm{g} / \mathrm{cm}^{2}$ located along the flight corridors near $50^{\circ}-60^{\circ} \mathrm{N}$. The global mean columns range from 1.6 to $5.0 \mu \mathrm{g} / \mathrm{cm}^{2}$ with a median value of $2.3 \mu \mathrm{g} / \mathrm{cm}^{2}$. The potential climate change caused by aircraft is assessed here by the global, annual mean instantaneous top of atmosphere radiative forcing (TOARF).

The global mean column burden of soot ranges from $0.07-0.20 \mathrm{ng}(\mathrm{soot}) / \mathrm{cm}^{2}$. The best current estimate of the sensitivity of TOARF to soot column burden, $\sim 3000 \mathrm{~W} / \mathrm{g}$ (soot), includes enhanced effects of absorbing aerosols in the upper troposphere above clouds [Haywood and Ramaswamy, 1998]. If aircraft-produced and background soot have similar properties, an upper limit of TOARF(soot) is $+0.006 \mathrm{~W} / \mathrm{m}^{2}$.

Assuming an $\mathrm{EI}(\mathrm{S})$ of $4 \times 10^{-4}$ and $100 \%$ conversion of sulfur to sulfate, the global mean $\mathrm{SO}_{4}$ column burden is $2.0-6.0 \mathrm{ng}\left(\mathrm{SO}_{4}\right) / \mathrm{cm}^{2}$. Assuming a sensitivity of $-215 \mathrm{~W} / \mathrm{g}\left(\mathrm{SO}_{4}\right)$ for relatively dry sulfate aerosols in the UT/LS [Haywood and Ramaswamy, 1998], the upper limit of the TOARF(sulfate) is $-0.013 \mathrm{~W} / \mathrm{m}^{2}$. Our TOARFs provide upper limits, since coagulation and sedimentation are ignored in our tracer simulation and $100 \%$ conversion of $\mathrm{SO}_{2}$ sulfur is assumed. Also, models with aerosol microphysics [Chuang et al., 1997] suggest $\sim 50 \%$ conversion. These TOARFs are approximately two orders of magnitude smaller than that due to cumulative anthropogenic $\mathrm{CO}_{2}$ emissions from fossil fuel and are of similar magnitude to TOARF due to subsonic aircraft $\mathrm{CO}_{2}$ emissions.

Concluding remarks. Our results from a tracer study for the 1992 aircraft fleet provide a useful quantitative assessment of aircraft effects for a wide range of potential atmospheric perturbations. The independent models participating show a modest range for the global mean accumulation of aircraft exhaust, ranging only over a factor of three despite the large differences in modeling the tropopause region. Our results are most useful as upper bounds to the accumulation of aircraft exhaust products because our simulation ignores photochemical and microphysical processes. Despite these limitations, we are able to place the aircraft environmental effects in perspective and rule out some hypotheses attributing observed changes in sulfate aerosol mass and $\mathrm{H}_{2} \mathrm{O}$ to aircraft. More accurate assessments of the atmospheric effects of aircraft will require 3-D atmospheric models with full photochemistry and/or microphysics.

Acknowledgments. This study was supported by the NASA AEAP and the Environment and Climate Programme of the European Community. We appreciate the graphical support by Karen Sage and the reviewers' comments.

\section{References}

Baughcum, S.L. et al., Scheduled civil aircraft emission inventories for 1992: Database development and analysis, $N A S A C R-4700,1996$.

Bekki, S. and J.A. Pyle, 2-D assessment of the impact of aircraft sulfur emissions on the stratospheric sulfate aerosol layer, J. Geophys. Res., 97, 15,839-15,847, 1992.

Berntsen, T., and I.S.A. Isaksen, A global three-dimensional CTM for the troposphere: 1. Model description and CO and ozone results, J. Geophys.Res., 102, 21,239, 1997.
Brasseur, G. et al., European scientific assessment of the atmospheric effects of aircraft emissions, Atmos. Env., 32, 2327-2422, 1998.

Chuang, C.C., et al., An assessment of the radiative effects of anthropogenic sulfate, J. Geophys. Res., 102, 3761$3778,1997$.

Cooke, W.F., and J.J.N. Wilson, A global black carbon aerosol model, J. Geophys. Res., 101, 19395-19409, 1996.

Curtius, J. et al., First direct sulfuric acid detection in the exhaust plume of a jet aircraft in flight, Geophys. Res. Lett., 25, 923-926, 1998 .

Fahey, D.W., et al., Emission measurements of the Concorde supersonic aircraft in the lower stratosphere, Science, 270, 70-74, 1995.

Friedl, R.R. (ed), Atmospheric effects of subsonic aircraft, NASA Ref. Publ. 1400, 1997.

Hannegan, B. et al., The dry stratosphere: A limit on cometary influx, Geophys. Res. Lett, 25, 1649-1652, 1998.

Haywood, J.M., and V. Ramaswamy, Global sensitivity studies of the direct radiative forcing due to anthropogenic sulfate and black carbon aerosols, 9. Geophys. Res., 103, 6043-6058, 1998.

Hofmann, D.J., Aircraft sulfur emissions, Nature, 349, 659, 1991

Jackman, C.H., et al., Past, present, and future modeled ozone trends with comparisons to observed trends, J. Geophys. Res. 101, 28,753-28,767, 1996

Kinnison, D.E., et al., The chemical and radiative effects of the Mt. Pinatubo eruption, J. Geophys. Res., 99, 25705$25731,1994$.

Kjellstrom, E., et al., The contribution of aircraft emissions to the atmospheric sulfur budget, Atmos. Env., submitted, 1998.

Liousse, C., et al., A global 3-D model study of carbonaceous aerosols, J. Geophys. Res., 101, 19,411-19,432, 1996.

Oltmans, S.J. and D.J. Hofmann, Increase in lower-stratospheric water at mid-latitude Northern Hemisphere site from 1981 to 1994 , Nature, 374, 146-149, 1995.

Penner, J.E., et al., Tropospheric nitrogen: A threedimensional study of sources, distribution, and deposition, J. Geophys. Res. 96, 959-990, 1991.

Pitari, G., et al., HSCT impact: The role of sulfate, NAT, and ice aerosols studied with a 2-D Model including aerosol physics, J.Geophys.Res., 98, 23,141, 1993.

Pitari, G., A numerical study of the possible perturbation of stratospheric dynamics due to Pinatubo aerosols: Implications for tracer transport, J.Atmos.Sci., 50, 2443, 1993.

Pueschel, R.F., et al., Soot aerosol in the lower stratosphere: Pole-to-pole variability and contribution by aircraft, $J$. Geophys. Res., 102, 13,113-13,118, 1997.

Rahmes, T.F., et al., Atmospheric distributions soot particles by current and future aircraft fleets and resulting radiative forcing on climate, $J$. Geophys. Res. 1998.

Sausen, R., and 1. Köhler, Simulating the global transport of nitrogen oxides emissions from aircraft. Ann. Geophys. 12, 394-402, 1994.

Schumann, U. et al. (eds), Pollutants from air traffic: Results of atmospheric research 1992-1997, DLR Mitt. 97. 04, Cologne, 289 pp., 1997.

Stolarski, R.S., et al. (eds), 1995 Scientific assessment of the atmospheric effects of stratospheric aircraft, NASA Ref. Publ., 1381, 1995 .

Wauben, W.M.F., et al., A 3-D CTM study of changes in atmospheric ozone due to aircraft $\mathrm{NO}_{x}$ emissions, Atm. Env., 31, 1819-1836, 1997.

Weaver, C. J., A. R. Douglass and D. B. Considine, A 5-year simulation of supersonic aircraft emission transport using a 3-D model, J. Geophys. Res., 101, 20975, 1996.

Weisenstein, D.K., et al., Potential impact of ' $\mathrm{SO}_{2}$ emissions from stratospheric aircraft on ozone, Geophys. Res. Lett., 23, 161-164, 1996.

Weisenstein, D.K., et al. The effect of sulfur emissions from HSCT aircraft: A 2-D model intercomparison, $J$. Geophys. Res., 103, 1527-1547, 1998.

Yue, G.K., et al., Stratospheric aerosol acidity, density, and refractive index deduced from SAGE-II and NMC temperature data, J. Geophys. Res., 99, 3727-3738, 1994.

corresponding author: M.Y. Danilin, AER, Inc., 840 Memorial Drive, Cambridge, MA 02139; danilin@aer.com

(Received June 30, 1998; revised August 21, 1998; accepted September 15, 1998.) 